Journal of Science Education Research

Journal homepage: www.journal.uny.ac.id/jser

JSER

\title{
The Different Effect of PBL, Inquiry, and DI on the Problem-Solving Skill in Science
}

\author{
Rina Ning Tyas ${ }^{1 *}$, Mundilarto ${ }^{2}$ \\ ${ }^{1,2}$ Post-Graduate Program, Universitas Negeri Yogyakarta \\ Corresponding Author. Email: rinaningtyas88@yahoo.com, mundilarto@uny.ac.id
}

Keywords:
PBL, Inquiry, DI,
and Problem
Solving Skill

\begin{abstract}
The purposes of this study were: (1) to analyze the different effect of PBL, inquiry, and DI on the problem-solving skill in science of the students; (2) to analyze the different effect of PBL and inquiry on the problem-solving skill in science of the students; (3) to analyze the different effect of PBL and DI on the problem-solving skill in science of the students; and (4) to analyze the different effect of inquiry and DI on the problem solving skill in science of the students. This research was a quasi-experiment with the problem-solving skill as the dependent variable, learning model (PBL, inquiry learning, and DI) as the independent variable, and prior knowledge as the covariance variable. The population of this research was grade VIII students of SMP N 1 Batang and the sample was three groups established using the cluster random sampling technique. The results of this study showed: (1) there is a different effect of PBL, inquiry, and DI on the problem-solving skill in science of the students; (2) there is no different effect of PBL and inquiry on the problem-solving skill in science of the students; (3) there is a different effect of PBL and DI on the problem solving skill in science of the students; and (4) there is a different effect of inquiry and DI on the problem solving skill in science of the students.
\end{abstract}

C2019 JSER. Yogyakarta State University

\section{INTRODUCTION}

The regulation of Minister of National Education No. 23 of 2006 on the competency standards of graduates of junior / MTs / SMPLB / Package B for Science and Technology study groups includes some of the skills. The skills are; the ability to think logically, critically, creatively, and innovatively, the ability to learn independently according to the potential, and ability to analyze and solve problems in daily life. A skill that becomes a hot topic in modern education is problem-solving skills.

Problem-solving skill is the ability to find out solutions for the problems using prior knowledge. Problem-solving skill is needed by students to adapt to face the conditions of learning in the future, both in the school or outside the school. Students should have the ability to master the material of learning and have the ability to implement it (Kirkley, 2003: 1).
Charles, et al (1987: 7) mentions seven thinking skills involved in the problem-solving process, namely: (a) understanding/compiling questions in a presented problem, (b) understanding the conditions and variables in the problem, (c) choosing / finding the needed data in solving the problem, (d) compiling sub-problems and choosing the right strategy to continue the process of problem-solving, (e) implementing strategy of solving the problem and solving the sub-problems appropriately, (f) providing a solution for the data of the presented problem, and (g) evaluating reasonable/explainable answers. This thinking skill might be a measuring tool for students' skills in solving a problem.

The fact occurs in education in Indonesia is the low ability of students in terms of the ability to understand scientific concepts and application in solving problems. This conclusion was from the results of the TIMSS 2003 International Science Report (Martin, et al, 2003: 292) and the report of PISA in 2009 (PISA, 2010: 151). This conclusion is 
consistent with the percentage of junior high school students graduating in Central Java Province in the 2012/2013 academic year. The report of the press conference for graduating of national education of SMP and equivalent stated that the percentage of graduating was 99.77 (Ministry of Education, 2013: 11). The results were lower than in other provinces in Central Java. In a smaller scope, the same problem occurs in SMP N 1 Batang. Based on the interviews with science teacher of grade VIII, found out that students have difficulty in answering science questions that require higher-order thinking skills to solve the presented problems.

The improvement of problem-solving skills might be through learning activities that facilitate students to become active learners. Problem-solving skills might achieve by students when the teacher can lead the students to construct knowledge and facilitate to engage in learning activities. Learning models of constructivist are problem-based learning (PBL), inquiry learning, discovery, cooperative learning, and project-based learning (Suparno, 2007: 63). Of the learning designs, the article attempt to apply PBL and inquiry learning to improve the problem-solving skills of students. The selection of the learning model was also motivated by the absence of PBL and inquiry in science learning in SMP N 1 Batang.

PBL is a learning model when teachers conduct learning in a real problem and bring students into a discussion of a problem in a small group. The model aims to create an active learning process, developing critical thinking, and problemsolving skills for students. PBL emphasizes the presentation of problems designed by imitating the complexity of problems in real life to find solutions.

PBL might apply in learning activities by referring to five syntaxes, namely: (1) providing orientation of problems to students, (2) organizing students to conduct research, (3) guiding a group investigations, (4) developing and presenting work, and (5) analyzing and evaluating the problem solving process (Arends, 2008: 57). The advantages of PBL are; preparing students to face problems in real-world situations, allowing students to become producers of knowledge, and can help students to develop communication, reasoning, and critical thinking skills (Widjajanti, 2011: 4).

The inquiry is a learning model designed to train students to carry out the research process. Research activities are carried out by involving students to problems with containing intellectual challenges. Students could try to find problemsolving through collecting and organizing data, and drawing conclusions (Joyce, et al, 2009: 207).

Inquiry learning is carried out by referring to four syntaxes: (1) identifying questions, (2) making hypotheses, (3) collecting data through experiments and analyzing data, and (4) evaluating hypotheses and making generalizations (Eggen \& Kauchak, 2012: 328). Through inquiry, students become the subject of active learning. Students not only can master the material, but also develop their thinking skills. Inquiry learning can significantly improve student learning outcomes, as well as improve problem-solving skills (Wena, 2008: 81).

Not only PBL and inquiry, but this particular research used also direct teaching (DI). DI is chosen based on the reason; DI is mostly used by teachers because considered as the most effective learning model in teaching and learning activities. DI is a learning model where the teacher transfers information or skills directly to students. This learning activity is goal-oriented and structured by the teacher. DI is applied in learning activities regarding four syntaxes, namely: (1) introduction and review, (2) presentation, (3) guided practice, and (4) independent training (Eggen \& Kauchak, 2012: 368).

Of the three learning models, the research will analyze the effectiveness of those learning models for problem-solving skills. The problems are: (1) what are the different effect of PBL, inquiry, and DI on the problem-solving skill in science of the students?; (2) what are the different effect of PBL and inquiry on the problem-solving skill in science of the students; (3) what are the different effect of PBL and DI on the problem-solving skill in science of the students; and (4) what are the different effect of inquiry and DI on the problem solving skill in science of the students.

Based on the problems, the particular research aimed (1) to analyze the different effect of PBL, inquiry, and DI on the problem-solving skill in science of the students; (2) to analyze the different effect of PBL and inquiry on the problem-solving skill in science of the students; (3) to analyze the different effect of PBL and DI on the problemsolving skill in science of the students; and (4) to analyze the different effect of inquiry and DI on the problem solving skill in science of the students.

This research is expected to contribute to the development of science and the quality of learning, especially to achieve the science learning process that is innovative, fun, meaningful and developing thinking skills. Moreover, practically, this article can improve problem-solving skills of students, and help science teachers to teach science with more interesting, fun, meaningful, and open insights, as well as encourage the implementation of various constructivist learning activities which aims to improve the quality of education. 


\section{METHOD}

Research Type

The research type was quasi-experimental using three sample groups. PBL used in the first experimental group; Inquiry used in the second experimental group; and DI used in the third experimental group. The control group was not used in this particular research because the school has not implemented the integrated science learning yet, while the design of the research material was integrated science material. So, it was not possible to have a control class with conventional learning.

The study was conducted to investigate the different the effect of the independent variables namely the learning model (PBL, inquiry, and DI) on the dependent variable, which is problem-solving skills. Aiming to minimize the possibility of the effect of uncontrolled other variables on the dependent variable in quasi-experimental studies, this article used covariance analysis and normalized gain (different in pretest and posttest scores) as the compared score. Covariance variables were prior knowledge variables which assuming the prior knowledge can effect on students' problem-solving skills outside the learning model. So, through covariance analysis, this article has "reform" the effect of the prior knowledge variable on the variable of problem-solving skills of the student.

Time and Place of the Research

The particular study conducted in grade VIII of SMPN 1 Batang N, Central Java Province, in the second semester of the 2012/2013 academic year.

\section{Target/ of the Research}

The population was students on grade VIII of SMP N 1 Batang, Central Java. The sample selected using cluster random sampling, which selected 3 classes of six classes randomly by lottery method. The interviews with science subject teachers found out that the class divisions in SMP N 1 Batang conducted randomly and no superior classes from the population. Here, it assumed that each class has the same ability.

\section{Research Procedures}

Before conducting the research, three classes were chosen as a sample group of the population, then obtained a class as the first experimental group, a class as the second experimental group, and a class as the third experimental group. Then, data for prior knowledge collected through test questions and pretest through problem-solving skills test questions.

After obtained data of prior knowledge and the pretest of problem-solving skills, the first sample group followed PBL, the second sample group followed inquiry learning, and the third sample group followed DI. Learning carried out for 6 hours or three meetings. After the learning, posttest was given to students to find out the result of treatment on the sample group. By the different between the pretest and posttest scores, gained the gain score for the problem-solving skills of students in each group.

Covariant Analysis used to test the first hypothesis, "There are different in the effect of PBL, inquiry, and DI on science problem-solving skills of students," by using the scores of initial knowledge as covariant variables and gain problem-solving skills as the dependent variable. The results of the gain analysis of problem-solving skills among sample groups after controlling prior knowledge determined the different the effect of the three learning models on students' science problemsolving skills. If the obtained score, at least a pair of sample groups that have a different score of science problem-solving skills, concluded that the research hypothesis accepted. Furthermore, a further test carried out to test the second, third, and fourth research hypotheses, which were to find out which pair of learning models has significant different the effect on scientific problem-solving skills of students. The research design carried out concisely and is presented in Table 1.

\section{Table 1. Research Design of Pretest-Posttest with Nonequivalent Control Group Design}

\begin{tabular}{c|ccc}
\hline Groups & Pretest & Treatment & Posttest \\
\hline Group 1 & $\mathrm{O}_{1}$ & $\mathrm{X}_{1}$ & $\mathrm{O}_{2}$ \\
Group 2 & $\mathrm{O}_{1}$ & $\mathrm{X}_{2}$ & $\mathrm{O}_{2}$ \\
Group 3 & $\mathrm{O}_{1}$ & $\mathrm{X}_{3}$ & $\mathrm{O}_{2}$ \\
\hline
\end{tabular}

Where:

$\mathrm{O}_{1}$ : Pretest

$\mathrm{O}_{2}$ : Posttest

$\mathrm{X}_{1}: \mathrm{PBL}$

$\mathrm{X}_{2}$ : Inquiry

$\mathrm{X}_{3}: \mathrm{DI}$

\section{Data Analysis Techniques}

The purpose of the quantitative analysis was to test the hypothesis. Covariant Analysis used to test the first hypothesis, "There are different the effect of PBL, inquiry, and DI on science problemsolving skills of students." Data on problem-solving skills obtained from normalized gain adapted from the calculation formula of normalized gain of Hake (1998: 65). The calculation formula is:

Where:

$$
\text { Gain }=\frac{S_{f}-S_{i}}{S_{\max }-S_{i}}
$$

$S_{f} \quad$ : Posttest score 
$S_{i} \quad$ : Pretest score

$S_{\max }:$ Maximum Score of test

Covariance analysis used to reduce error variance derived from the effect of covariant variables (prior knowledge) which are believed can make a bias on the results of the analysis. In determining a covariance variable, several things need to be considered, such: (a) covariant variables believed influencing the dependent variable, but were not relevant to the research objectives, (b) difficult to control the covariance variables, (c) covariant variables were not affected by treatment / independent variable (Kirk, 1995: 710).

Based on theoretical studies, researchers believe, that there is a strong relationship between prior knowledge and problem-solving skills. Prior knowledge is a students' knowledge before learning activities obtained from previous learning that effect on the formation of new knowledge. The different of prior knowledge of each student feared could affect the problem-solving skills, outside the effect of the learning model as an independent variable. Whereas, to control each student has the equivalent prior knowledge was not possible due to the cluster random sampling of class groups used as the sampling technique. By this technique, a sample group was possible with different prior knowledge. For the last requirement, the covariant variables are not influenced by independent variables can be fulfilled by taking the data of covariance variable before treatment. Therefore, data collection of prior knowledge carried out before learning activities.

The results of the covariance analysis can answer whether the first hypothesis accepted or not. When jumped into conclusion, there are different the effect of the three learning models on science problem-solving skills of students, and then conducted further tests (Bonferroni test). The further test carried out to answer the second, third, and fourth hypotheses, that, knowing which pair of learning models had significant different the effect on science problem-solving skills of students.

Before the hypothesis test, several assumptions must be fulfilled for covariance analysis, aiming the results of the analysis is strong or undoubtful. The assumptions were: (1) normality data, (2) error independent, (3) homogeneity of variance, (4) random sampling, (5) regression of linearity, and 6) regression homogeneity (Gamst et al, 2008: 458).

\section{RESULT}

The data were the implementation of learning activities from each treatment, prior knowledge, and pretest and posttest on problem-solving skills.

Data on the Implementation of Learning Activities

To ensure the feasibility of treatment in each experimental group, observations carried out on the implementation of learning activities. It used the observation sheets based on learning activities in line with the syntax of each learning model. Learning activities carried out in each group were observed by two observers using the observation sheet of the implementation of learning activities. From each meeting, the number of learning activities is calculated. The number of activities is then divided by the total number of learning activities at each meeting. The results of the division are then multiplied by $100 \%$ to obtain the percentage of the implementation of the learning activities from each observer.

From Table 2, the average score was more than $80 \%$ of learning activities in each learning model among the PBL, inquiry, and DI. Then, it concluded that almost all the learning activities planned in the Lesson Plan have very well implemented. Some learning activities that are not implemented are final learning activities, such as activities drawing conclusions or closing the learning.

Table 2. Percentage of Implementation of Learning Activities

\begin{tabular}{|l|c|c|c|c|c|c|}
\hline \multirow{2}{*}{$\begin{array}{l}\text { Learning } \\
\text { Model }\end{array}$} & \multicolumn{6}{|c|}{ Percentage of Implementation of Learning Activities } \\
\cline { 2 - 7 } & \multicolumn{2}{|c|}{ First Meeting } & \multicolumn{2}{c|}{ Second Meeting } & \multicolumn{2}{c|}{ Third Meeting } \\
\cline { 2 - 7 } & P1 & P2 & P1 & P2 & P1 & P2 \\
\hline PBL & 87,5 & 100 & 93,75 & 100 & 87,5 & 87,5 \\
\hline Inquiry & 94,44 & 100 & 94,44 & 94,44 & 94,44 & 94,44 \\
\hline DI & 100 & 100 & 100 & 100 & 90 & 90 \\
\hline
\end{tabular}

\section{Data of Prior Knowledge}

Based on table 3, there are different in the mean score of prior knowledge among the sample groups. The mean score of the prior knowledge of the PBL group was slightly higher than the inquiry and DI groups. 
Table 3. Description of Prior Knowledge Data

\begin{tabular}{|c|l|c|c|c|}
\hline No & Description & $\boldsymbol{P B L}$ & Inquiry & DI \\
\hline 1 & $\begin{array}{l}\text { Number of } \\
\text { Data }\end{array}$ & 28 & 32 & 28 \\
\hline 2 & Mean & 4,425 & 4,189 & 3,919 \\
\hline 3 & $\begin{array}{l}\text { Minimum } \\
\text { Score }\end{array}$ & 3,742 & 3,606 & 3,606 \\
\hline 4 & $\begin{array}{l}\text { Maximum } \\
\text { Score }\end{array}$ & 5,000 & 4,690 & 4,583 \\
\hline 5 & $\begin{array}{l}\text { Standard } \\
\text { Deviation }\end{array}$ & 0,322 & 0,330 & 0,274 \\
\hline 6 & Variance & 0,104 & 0,109 & 0,075 \\
\hline
\end{tabular}

Data of Problem Solving Skills

The test of problem-solving skills conducted at the beginning and the end of the learning activity. Data of pretest of problem-solving skills collected through tests before treatment. On the other hand, data of posttest of problem-solving skills collected through tests after treatment.

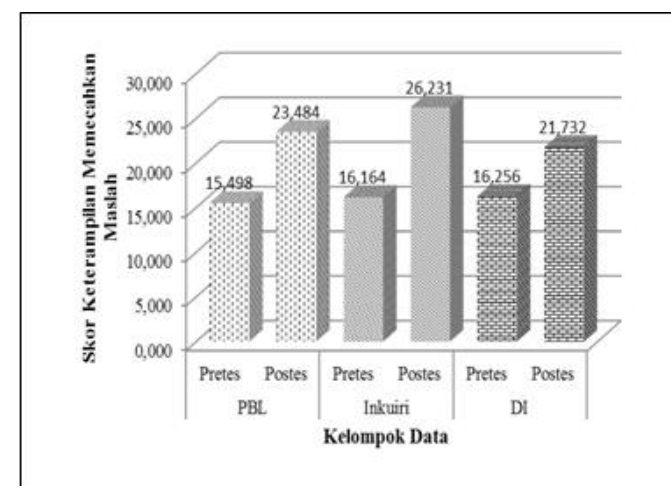

Figure 1. Graph of Comparison of Mean score of Pretest and Posttest on Problem Solving Skills

Based on Figure 1, the average score of pretest in all groups has slightly different. Means, the mean score of problem-solving skills among the three groups before treatment did not show significant different. However, the mean score of problem-solving skills after treatment in the DI group looked much different compare to the PBL and inquiry group. Based on the graph, there was also an increase in problem-solving skills from the different in the score of pretest and posttest. Increasing the problem-solving skills in the PBL group and inquiry was not much different, while the lowest score in the increasing the problem-solving skills was the DI group.

In the quantitative test, researchers calculated the normalized gain of problem-solving skills through the different between pretest and posttest of problem-solving skills to determine the different in problem-solving skills in each group.

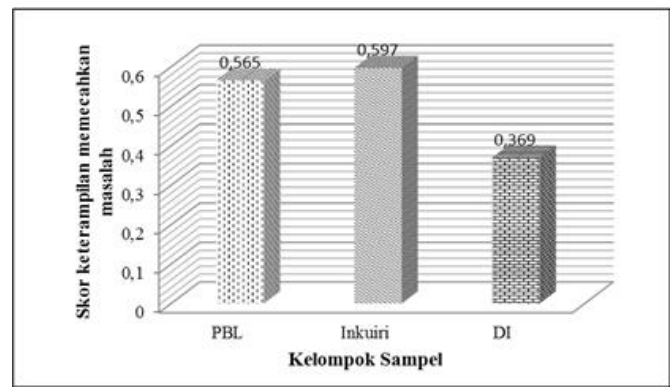

Figure 2. Graph of Comparison of Mean score of Problem Solving Skills

Based on figure 2, the mean gain score of problem-solving skills in each group was different. The inquiry group has the highest mean score of 0.597. Second, the PBL group has a mean score of 0.565 . And, the DI group has the lowest mean score of 0.369 .

\section{Discussion}

The objectives of the research were: to analyze the different effect of PBL, inquiry, and DI on the problem-solving skill in science of the students; (2) to analyze the different effect of PBL and inquiry on the problem-solving skill in science of the students; (3) to analyze the different effect of PBL and DI on the problem-solving skill in science of the students; and (4) to analyze the different effect of inquiry and DI on the problem solving skill in science of the students. A quasi-experimental study using three sample groups was conducted to achieve these objectives. Each sample group treated with different treatments. The first group followed PBL, the second group followed inquiry learning, and the third group followed DI. Before the learning, each group provided a test for prior knowledge to obtain data of prior knowledge as covariant variables and pretest-posttest of problemsolving skills to obtain data on problem-solving skills as the dependent variable.

Analysis results in the different the effect of learning models on problem-solving skills used to test the first hypothesis; namely "There are different the effect of PBL, inquiry, and DI on problemsolving skills of students." Through covariance analysis, the $F$ value for the learning model obtained at 13.294 with a significant score of 0.000 . The significant value of the learning model is smaller than $\alpha(0.05)$, means that, after applied the prior knowledge variable, at least, there was a pair of sample groups have significantly different on problem-solving skills. Therefore, the first hypothesis based on theoretical studies accepted.

Bonferroni test conducted to find out which pair of learning models has significantly different effects on science problem-solving skills. From the 
test results, it obtained a significant score of the different mean score of gain on problem-solving skills, pair of PBL and inquiry models of 0.790; pair of PBL and DI models of 0.003; and pair of inquiry model and DI of 0,000 .

The results of the Bonferroni test showed: (1) there is no different the effect of PBL and inquiry on science problem-solving skills of students; (2) there are different the effect of PBL and DI on science problem-solving skills of students; and (3) there are different the effect of inquiry and DI on scientific problem solving skills of students. In short, means that increasing the mean score in problem-solving skills in the PBL and inquiry group was not significantly different, but the increase was significantly different from the DI group. The increasing of the mean score in problemsolving skills in the DI group was far lower than the PBL and inquiry group.

PBL and inquiry might claim to have the same effectiveness in improving problem-solving skills due to those learning models are not much different. Hmelo-Silver, et al (2007: 99) stated that PBL and inquiry are both strong and effective learning models in mastering concepts and soft skills. PBL and inquiry have similarities which are believed to have an effect on problem-solving skills of students, such as (1) the syntax of PBL and inquiry focuses on problems and lead students to solve the problems; (2) management of learning activities in groups; and (3) PBL and inquiry-based on Piaget's constructivism theory, theory of meaningful learning from David Ausubel, Vigotsky's learning theory, and Bruner's learning theory.

The mean of increasing the problem-solving skills in the DI group is known to be far lower than the PBL group and inquiry. Then, it concluded that DI is less effective in improving problem-solving skills compared to PBL and inquiry. The reasons were (1) syntax of DI lead the mastery of structured procedural skills with the approach of teacher center, and (2) DI based on Albert Bandura's behavior modeling theory.

\section{Problem Based Learning (PBL)}

PBL is student-centered learning. Learning begins with a real problem and all learning activities lead to finding solutions to the problems. Students provided the opportunity to construct their knowledge through activities of problem-solving in groups. This activity is in line with Piaget's constructivist theory and Bruner's theory which emphasizes the students' participation in the process of discovering, processing information, and building knowledge.

PBL activities of the particular research began with the first syntax of PBL, namely problem orientation. The teacher invited students to remember the material that has learned and motivated the students by presenting problems on images. The second syntax, organized students to conduct research. The teacher divided students into groups to work on learning activities according to the LKPD. Students provided news quote or story excerpts that contained problems to be identified and formulated. The third syntax, it guided the investigations through activities that lead the students to find solutions to the problems using prior knowledge and collected materials. The results of the solutions, made by each group, are then presented in the syntax of developing and presenting the work. The last syntax, it analyzed and evaluated the work. In this syntax, the teacher played the role of giving responses to the presentations, discussions, suitability the class discussions with theory, and providing evaluations to groups that have not worked well.

Presentation of a problem in PBL is in the first and second syntax. Presentation of the problems can encourage the students to get used to and do not feel strange dealing with various problems. Hudgins et al (1983: 353) stated that various problems provided opportunities for students to practice various problem-solving processes. So, they can help students to solve problems well. The more frequent students practice in solving problems, the better the ability and speed of students to deal with problems (Hendric et al, 2006: 927).

The problems used in PBL are authentic problems commonly encountered by students in real life. The use of real problems can increase motivation and challenge. Motivation can increase because students realize that the material to be learned has benefits in everyday life. Morales-Mann \& Kaitell (2001: 13) states that the problems that are usually encountered in real life might be a stimulus for students to learn problem-solving skills. Moreover, real problems of ill-defined problems can also pose challenges for students to find solutions compared to when students are faced with welldefined problems (Savery, 2006: 13).

The use of real problems also plays a role in solving a new problem (transfers). Santrock (2009: 46) states that, when situations are faced similar to those learned, transfers can occur easily. In sum, learning activities that use real problems will make easier for students to apply their experience and knowledge during learning to solve a new problem encountered.

In the particular study, group discussion activities used in the problem-solving process in PBL. The discussion activities had a positive influence on problem-solving skills. Managing PBL activities in groups makes student having a better 
understanding than if constructed individually. The reason is, the knowledge gained comes from more diverse thoughts. Following the Vygotsky's learning theory of PBL, stated that the social interactions during group discussions can encourage the formation of new ideas and enrich intellectual development. Ideas or experiences obtained during a dialogue with other students will also be remembered more accurately and effectively by students (Ormrod, 2003: 246).

Several studies carried out to investigate the effect of PBL implementation on problem-solving skills. A research conducted by Morales-Mann \& Kaitell (2001: 13), describe the learning experience of students during PBL implementation. From the opinions of students, stated that the differences faced by students during the implementation of PBL were the existence of group work and problemsolving activities than other learning. The advantages for students from the results of the learning process are increasing the learning autonomy, critical thinking skills, problem-solving skills, and communication skills. Research by Choi (2004: 712) also showed a positive effect on the implementation of problem-based learning to student learning outcomes and problem-solving skills.

\section{Inquiry Learning}

Students in the second sample group followed the inquiry model. First, the teacher invited students to remember the previous material of learning and convey examples of daily events related to the material to be studied. Entering the first syntax of identifying problems/questions, the teacher divides students into groups and presents the problems. The second syntax is formulating the hypotheses. The teacher requested the students to use their prior knowledge to propose a hypothesis. In the third syntax, collecting and analyzing, the teacher guided students to investigate the proposed hypothesis through experimental activities. The collected data from experiments were analyzed by answering questions in the LKPD as a reference in order the students reached the expected conclusions. The last syntax is assessing hypotheses and generalizations. The teacher requested students to present data, analysis of data, concluding, and suitability between hypotheses and experimental results. The presentation responded by the teacher through class discussions. The conclusion of the discussion generalized into a theory.

A characteristic of inquiry learning is the presumption or hypothesis of the problem. The hypothesis formulation can find out the prior knowledge of the student. So, if there is a misconception occurs, it can be corrected in the learning process due to prior knowledge is the basis in the construction of new knowledge. In line with David Ausubel's meaningful learning theory, stated that learning activities connecting new information with prior knowledge may state as meaningful learning that facilitates the transfer to improve better the problem-solving skills (Ormrod, 2003: 276).

Hypothesis investigation activities in inquiry learning carried out through experimental activities using real media. Carin \& Sund (1989: 45) argue that there is no learning without activities involving physical, mental, and social. Experimental activities can assure the students to feel that they are in daily activities, and also realize that learning activities are useful for real life. Learning activities that are considered interesting and useful, can affect students' motivation, so that information processing occurs. Through the activities of observing, hearing, touching, smelling, measuring, and counting during experimental activities might be a basic means to obtain new knowledge (Rustaman, 2005: 5).

Experimental activities provide direct experience for students to discover and construct their knowledge through scientific work. Through experimental activities, students who have misconceptions may experience cognitive conflict when the experiment result is different from the proposed hypothesis. So, the misconceptions can be corrected (Berg, 1991: 18). For students whose prior knowledge is appropriate, they can obtain a stronger new knowledge when the hypothesis is proven in experimental activities.

Same with PBL, inquiry learning also carried out in groups. Students have the opportunity to work in a group to look for problem-solving until finding the answer. Discussion activities facilitate students to obtain a better understanding of concepts. Ranee \& Kolari (2003: 196) stated that failure to solve problems is usually caused by low mastery of concepts. Therefore, understanding the concept is an important foundation in problemsolving skills. Understanding the concept facilitates the transfer of knowledge in various problems to obtain better problem-solving skills.

\section{Direct Teaching (DI)}

DI carried out in the third sample group. DI, a learning method is usually used by teachers in conventional learning. The research activity begins with inviting students to remember the last material and giving questions about the material of the learning to motivate the students. The second syntax was the presentation. The teacher explained the material to students. The teacher also carried out a demonstration so that students could prove the theory just described by the teacher. Beside teaching concepts, the teacher also explained the ways to solve the question of concept application. The next syntax is a guided practice. At this stage, the teacher 
guides students in solving the questions in a way that presented in the previous stage. The last stage is an independent practice. The teacher requested the students to look for other examples of the material and students should practice to solve it.

Problem-solving skills in DI group showed the lowest score compared to PBL group and inquiry. The reason believed as the influential factor was teacher-centered learning model. The theoretical foundation of DI is a behavior modeling theory (Albert Bandura) that places the teacher as a model in the learning activities of students.

Materials and skills in DI taught through presentation activities. This presentation activity causes students; not to have the opportunity to explore prior knowledge, and discover and build their knowledge. Prior knowledge and construction of knowledge play a role in forming new knowledge in students. When understanding the concept was not well constructed and not strongly attached to the students, the transfer is difficult to occur which causes the low of students' problem-solving skills.

In the implementation of the syntax, the presentation of the teacher also uses demonstration activities. However, this activity is also not interesting for students. The results of the demonstration may be predicted by students based on the explained theory. Here, students were poor motivation and challenging.

Woolfolk (2009: 362) stated that DI aimed to communicate a large amount of material to students in a limited time. When the material is broad with limited time, DI may be the best choice of the appropriate learning model. Moreover, DI is also appropriate for teaching well-structured procedural skills and taught step by step (Eggen \& Kauchak, 2012: 364). The syntax of DI is appropriate for training skills with a clear step of mastery, not to solve problems with unclearly structured steps. Therefore, DI may more be appropriate for cognitive and affective goals at a low taxonomic level and less appropriate for teaching problem-solving skills. Supported by the opinion of Eggen \& Kauchak (2012: 364), states that DI is not appropriate for teaching social skills or creativity, higher-order thinking skills, and abstracts.

\section{CONCLUSION}

\section{Conclusion}

The results of this study showed (1) based on the covariance analysis; the $\mathrm{F}$ value for the learning model is 13,294 with a significance of 0,000 . So, there is a different effect of PBL, inquiry, and DI on the problem-solving skill in science of the students; (2) Based on the further test (Bonferroni test); the significant score of the different mean score of gain on problem-solving skills, pair of PBL and inquiry models is 0.790 . So, there is no different effect of PBL and inquiry on the problem-solving skill in science of the students; (3) Based on the further test (Bonferroni test); the significant score of the different mean score of gain on problem-solving skills, pair of PBL and DI models is 0.003 . So, there is a different effect of PBL and DI on the problem solving skill in science of the students; and (4) Based on the further test (Bonferroni test); the significant score of the different mean score of gain on problem-solving skills, pair of inquiry model and DI is 0,000 . So, there is a different effect of inquiry and DI on the problem solving skill in science of the students.

\section{Suggestion}

The particular article proposed suggestions (1) needed activities with a focus on problemsolving aiming to improve problem-solving skills learning activities, such as PBL and inquiry, and (2) the dependent variable was only problem-solving skills. Then, based on observations during the learning process, there arise other variables from the effect of PBL, inquiry, and DI. Therefore, further research is needed on the effect of these lesson methods.

\section{REFERENCES}

Berg, E.V.D. (1991). Miskonsepsi fisika dan remidiasi. Salatiga: Universitas Satya Wacana (UKSW).

Carin, A.A., \& Sund, R.B. (1989). Teaching science through discovery (sixth edition). Colombus, Ohio: Merrill Publishing Company.

Charles, R., Lester, F., \& O’Daffer, P. (1994). How to evaluate progress in problems solving. Virginia: National Council of teachers of Mathematics.

Choi, H. (2004). The effects of PBL (Problem Based Learning) on metacognicition, critical thinking, and problem solving process of nursing students. Taehan Kanho Hakhoe Chi, 34(5), 712-721.

Djamilah Bondan Widjajanti. (2011). Problem Based Learning dan contoh implementasinya. Yogyakarta: UNY.

Eggen, P., \& Kauchack, D. (2012). Strategi dan model pembelajaran mengajarkan konten dan keterampilan berpikir. (Terjemahan Satrio Wahono). Boston: Pearson Education, Inc. (Buku asli diterbitkan tahun 2012)

Gamst, G., Meyer, L.S, \& Guarino, A.J. (2008). Analysis of variance designs a conceptual and computational approach with SPSS and $S A S$. New York: Cambridge University Press. 
Hake, R.R. (1998). Interactive-engagement versus traditional method: A six-thousand-student survey of mechanics test data for introductory physics course. American Journal of Physics Teachers, 66 (1), 64-74.

Hendric, W.D., Andrieu, S.C., Chadwick, D.G., Chmar, J.E., Cole, J.R., George, M.C., Glickman, G.N., et al. (2006). Educational strategies associated with development of problem solving, critical thinking, and selfdirected learning. Journal of Dental Education, 70(9), 925-936.

Hmelo-Silver, C.E., Duncan, R.G., \& Chinn, C.A. (2007). Scaffolding and achievent in problem based learning and inquiry learning : A response to Kirschner, Sweller, and Clark (2006). Educational Pychologist, 42(2), 99107.

Hudgins, B.B, Phye, G.D, Schau, C.G, . (1983). Educational psychology. San Francisco: F.E. Peacock Publishers, Inc.

Joyce, B., Weil, M., \& Calhoun, E. (2009). Models of teaching. (Terjemahan Ahmad Fawaid \& Ateilla Mirza). Yogyakarta: Pustaka Pelajar.

Kemdikbud. (2013). Konferensi pers hasil UN SMPsederajat tahun ajaran 2012/2013. Diakses pada tanggal 6 Juli 2013, dari http://118.98.166.62/content /dokumen/umum/konpers-un-smp.html

Kirk, R.E. (1995). Experimental Design: procedures for the behavioral sciences. California: ITP.

Kirkley, J. (2003). Principle for teaching problem solving. Indiana : Plato Learning Inc.

Martin, M.O., Mullis, I.V.S., Chrostowski, S.J. (2003). TIMSS 2003 technical report. Chestnut Hill: Boston College .

Morales-Mann, E.T. \& Kaitell, C.A. (2001). Problem based learning in a new Canadian curriculum. Journal of Advanced Nursing, 33(1), 13-19.
Ormrod, J.E. (2003). Educational psychology: developing learners. New Jersey: Pearson Education, Inc.

PISA. (2010). PISA 2009 results: what students know and can do - student performance in reading, mathematics and science (Volume I). Diakses pada tanggal 26 Juli 2012, dari http://www.oecd-ilibrary.org/education/pisa2009-results -what-students-know-and-cando_9789264091450-en

Ranee, C.S., \& Kolari, S. (2003). Promoting the conceptual understanding of engineering students through visualisation. Global Journal of Enginering Education, 7(2), 189200.

Rustaman, N.Y. (Juli 2005). Perkembangan penelitian pembelajaran berbasis inkuiri dalam pendidikan sains. Makalah disajikan dalam Seminar Nasional II Himpunan Ikatan Sarjana dan Pemerhati Pendidikan IPA Indonesia, di FMIPA UPI.

Santrock, J.W. (2009). Psikologi Pendidikan Edisi 3 (Terjemahan Diana Angelica). New York: McGraw Hill. (Buku asli diterbitkan tahun 2008)

Savery, J.R. (2006). Overview of Problem based Learning: Definition and distinction. International Journal of Problem based Learning, 1(1), 3, 8-20.

Suparno, P. (2007). Metodologi pembelajaran fisika konstruktivistik \& menyenangkan. Yogyakarta: Universitas Sanata Dharma.

Wena, M. (2008). Strategi pembelajaran inovatif kontemporer: suatu tinjauan konseptual operasional. Jakarta: PT Bumi Aksara. 